This is the final peer-reviewed accepted manuscript of

Vanucci, S.; GUIDI, FLAVIO; PISTOCCHI, ROSSELLA; Long, R. A.: Phylogenetic structure of bacterial assemblages co-occurring with Ostreopsis cf. ovata bloom. HARMFUL ALGAE 55, p. 269-271. ISSN 15689883.

DOI: 10.1016/j.hal.2016.04.003

The final published version is available online at: $h$ ttp://dx.doi.org/10.1016/j.hal.2016.04.003

Rights / License: The terms and conditions for the reuse of this version of the manuscript are specified in the publishing policy. For all terms of use and more information see the publisher's website. 


\section{Phylogenetic structure of bacterial assemblages co-occurring with Ostreopsis cf. ovata bloom}

Si vana Vanuccia $^{\mathrm{a} *}$

si vana vanucci@unime it

\section{F avio Guidi}

Rosse a Pistocch

Richard A Long

aDepartment of Chemica Bio ogica Pharmaceutica and Environmenta Sciences (ChiBioFarAm) University of Messina Via e Ferdinando Stagno d'A contres $3198166 \mathrm{~S}$ Agata Messina tay

bDepartment of Bio ogica Geo ogica and Environmenta Sciences (BiGeA) University of Bo ogna Via S'A berto 16348123 Ravenna ta y

'Department of Bio ogica Sciences F orida A\&M University Ta ahassee FL 32307 United States

*ECorresponding author Te : +39 3475714315 ; fax: +39 0-544 937411

\section{Abstract}

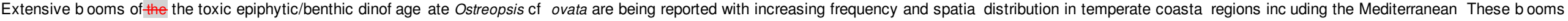

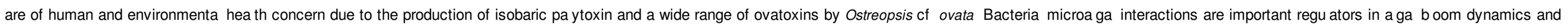

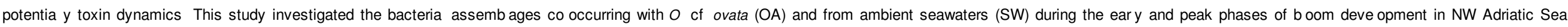
Fractions of the bacteria assemb ages co occurring with $O$ cf ovata $(\mathrm{OA})$ and more $\mathrm{c}$ ose $y$ associated to the muci age ayer (LA) embedding $O$ cf ovata ce $s$ were a so reported

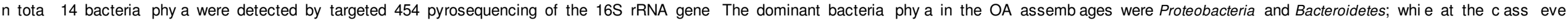

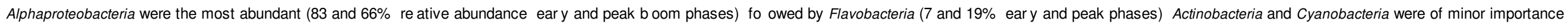

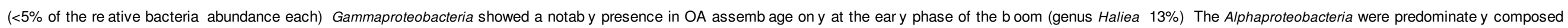

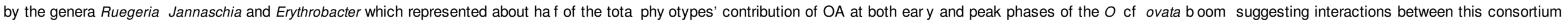
and the microa ga Moreover the highest contribution of Ruegeria (30\% of the tota phy otypes) was observed at the ear y phase of the b oom in LA assemb age

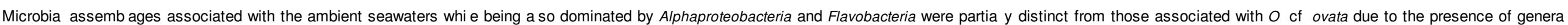
a most not retrieved in the atter assemb ages

Keywords: Ostreopsis; 柾oxic dinof age ate; HAB associated bacteria; Pyrosequencing Bacterialdiversity-Ruegeria; Haliea; Jannaschia

\section{Introduction}

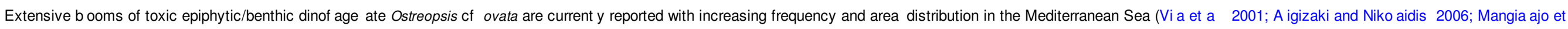

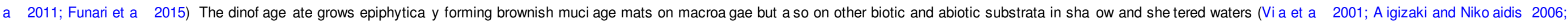

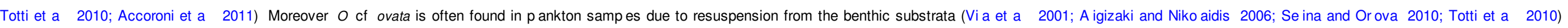

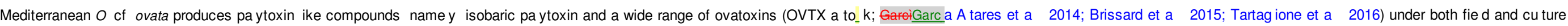

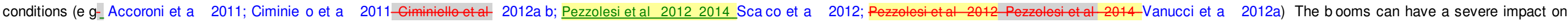

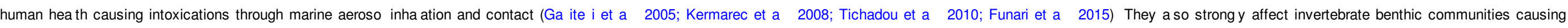




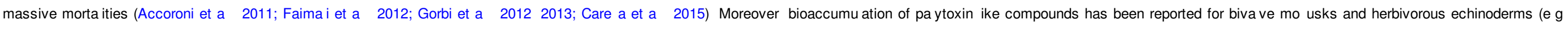

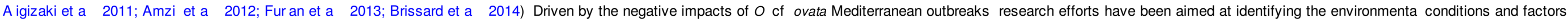

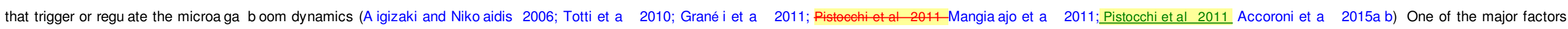

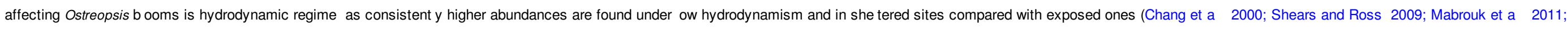
Se ina et a 2014)

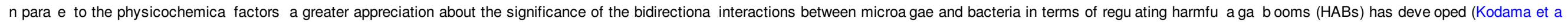

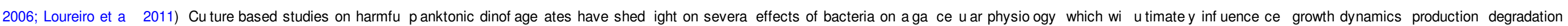

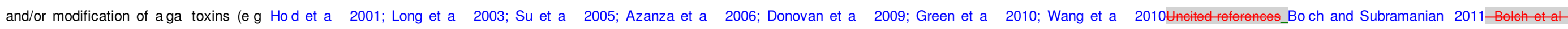

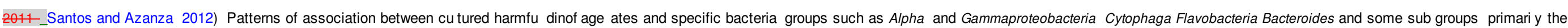

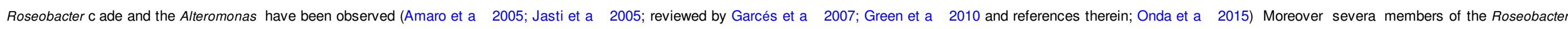

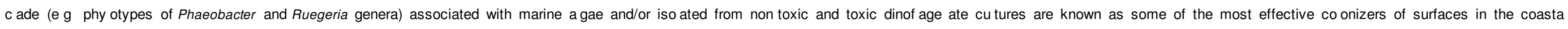

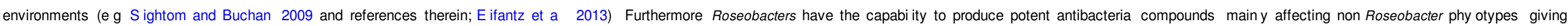

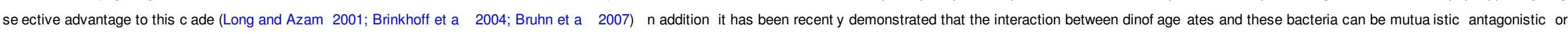

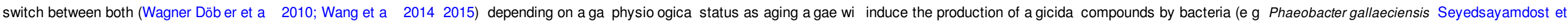
a 2011 2014; Ruegeria sp TM1040 Ric ea et a 2012) which cou d have an important ro e in the dec ining stages of a ga booms (Ric ea et a 2012)

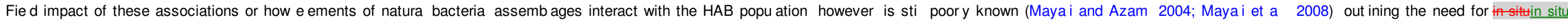

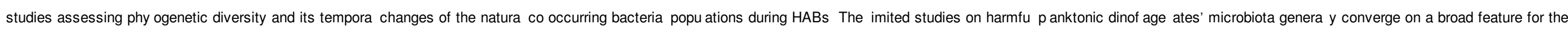
dominance of the two bacteria groups the Rhodobacterales (Alphaproteobacteria) and Cytophaga Flavobacteria Bacteroides (Bacteroidetes) during booms (Garcés et a 2007; Jones et a 2010; Park et a 2015)

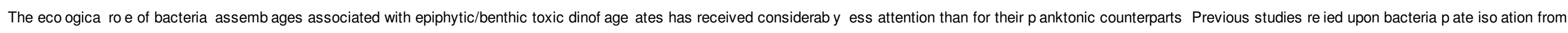

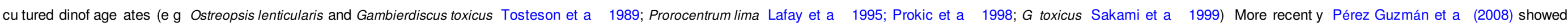

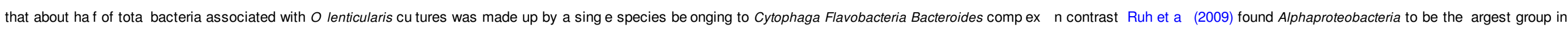

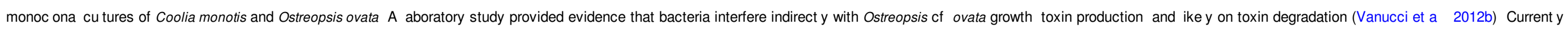
there is no phy ogenetic data on the natura bacteria assemb ages associated with $O$ cf-_ovata b ooms and more genera y with b ooms of benthic dinof age ates

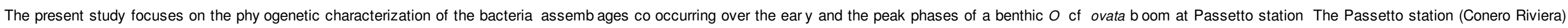

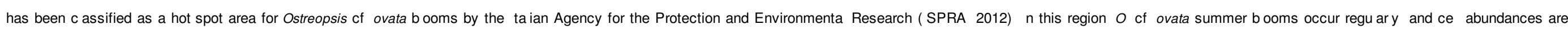

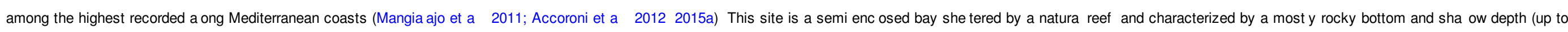

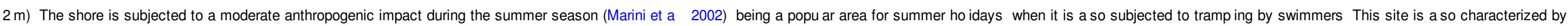

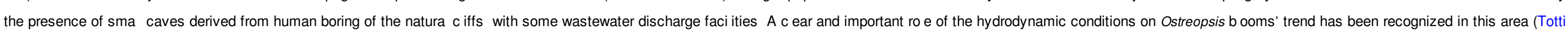

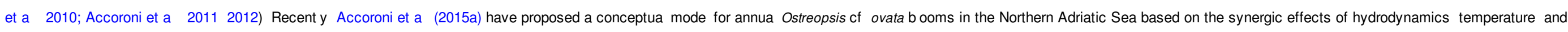

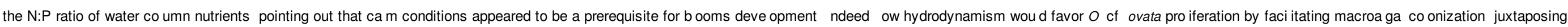
of the microa ga ce $\mathrm{s}$ and forming muci age mats (Via et a 2001; Totti et a 2010) which are known to be hotspots for microorganisms interactions (e g Co e et a 2014ab; Carreira et a 2015)

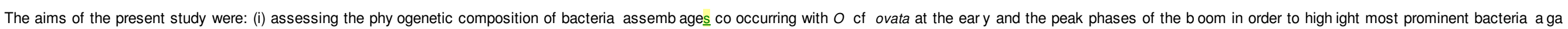

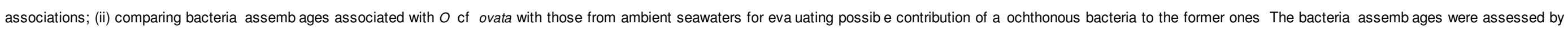
high throughput para e tag sequencing (454 pyrosequencing)

\section{Materials and methods}




\subsection{Study area and samples collection}

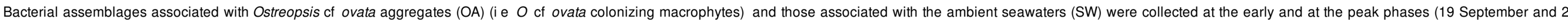
October 2012 respectively) of an $\mathrm{O}$ cf ovata bloom along the coast of North western Adriatic Sea (Passetto taly $43^{\circ} 3638$ - Nand $13^{\circ} 3220-\mathrm{N}$ and $13^{\circ} 3220 \mathrm{E}$ )

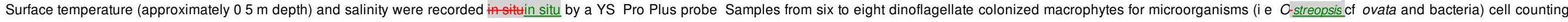

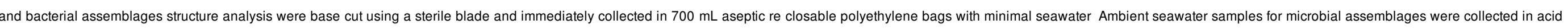

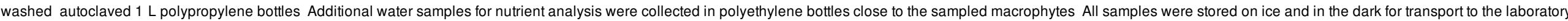

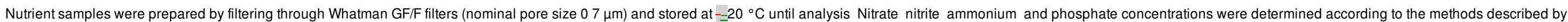
Strickland and Parsons (1972) using an Autoanalyzer QuAAtro Axflow

\subsection{0. ef. ovataO. cf. ovata and bacterial enumeration}

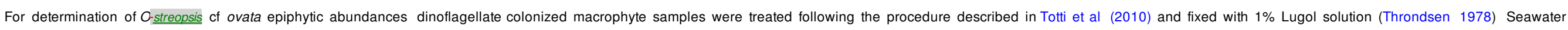

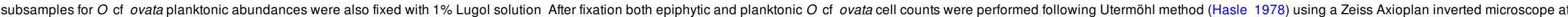
320 \#x $_{\underline{x}}$ magnification under bright field and phase contrast illumination

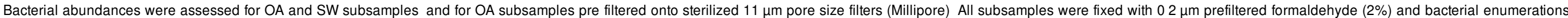

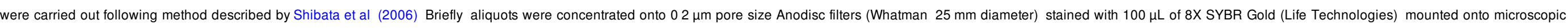

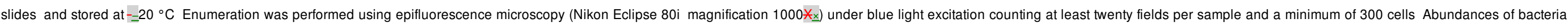

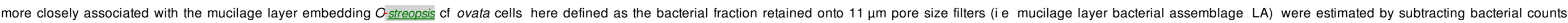
obtained for $11 \mu \mathrm{m}$ prefiltered $\mathrm{OA}$ subsamples to counts obtained for $\mathrm{OA}$ subsamples

\subsection{DNA samples processing and extraction}

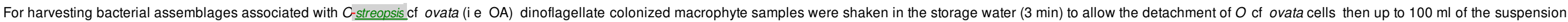

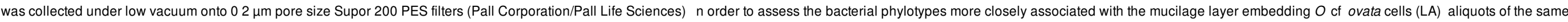

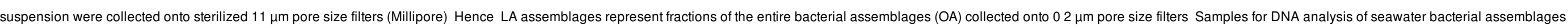

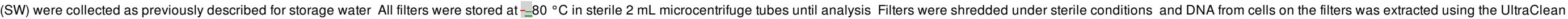
Soil DNA isolation kit (MoBio Laboratories) according to the manufacturer's instructions DNA concentrations and purity were determined with a NanoDrop 2000 spectrophotometer (Thermo Scientific Wilmington DE)

\subsubsection{16S rDNA pyrosequencing}

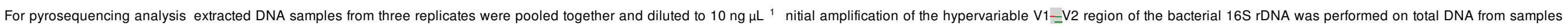

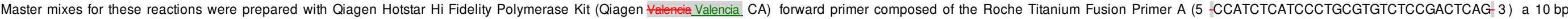

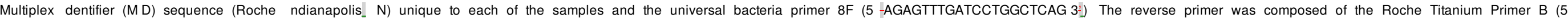

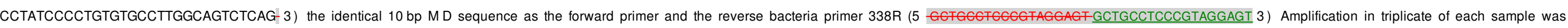

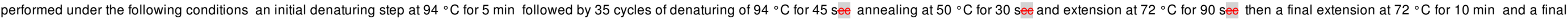

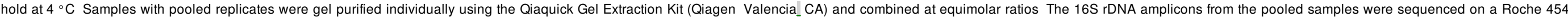

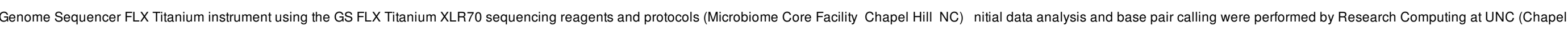
Hill NC)

\subsection{Sequence processing and diversity analysis}




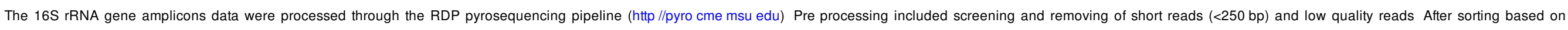

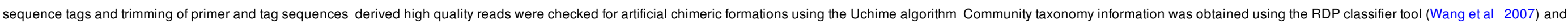

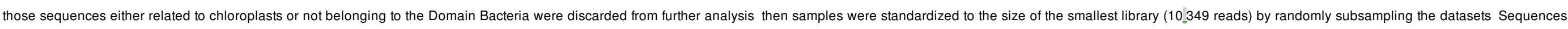

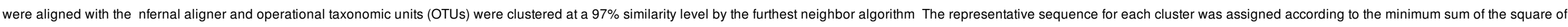

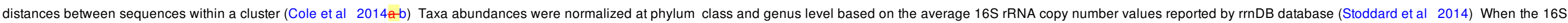

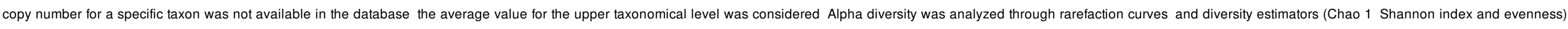
were calculated

\subsection{Statistical analysis}

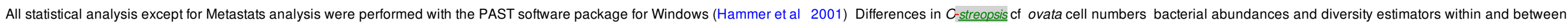

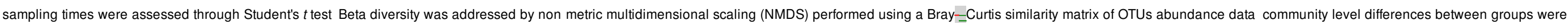

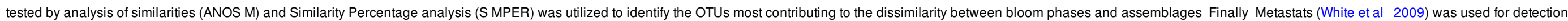
of differences in contribution of bacterial OTUs among samples Statistical significance was set at $p-<005$ for all the analysis

\section{Results}

\subsection{Environmental conditions and cell abundances}

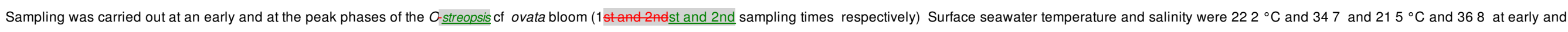

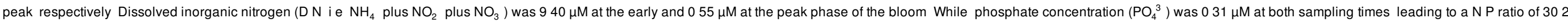
and 18 (1 stand 2 ndst and 2nd sampling respectively)

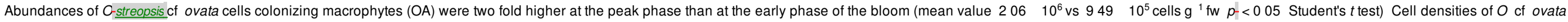
in ambient seawater samples (SW) were on average 198 and $310 \quad 10^{4}$ cells L ${ }^{1}$ at the early and peak phase respectively $(p->05$ Student's $t$ test)

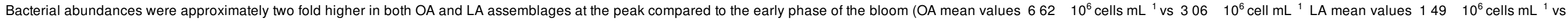

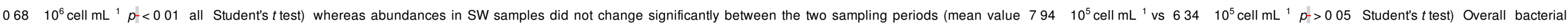
abundances were almost one order of magnitude higher in OA than in SW samples $(p-<001$ Student's $t$ test)

\subsection{Diversity of microbial assemblages}

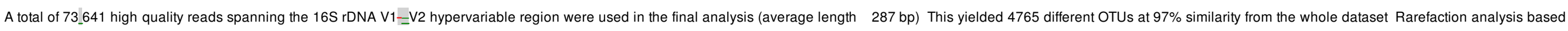

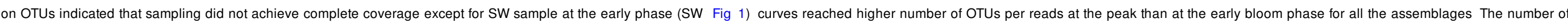

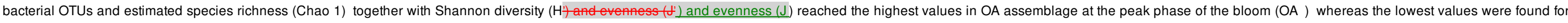

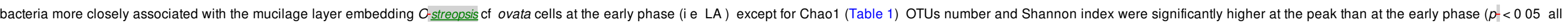

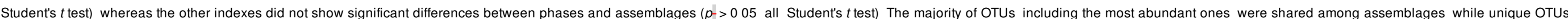
(31 6\% of the total OTUs in OA and $309 \%$ in SW assemblages) were mainly represented by singletons ( $60 \%$ ) 


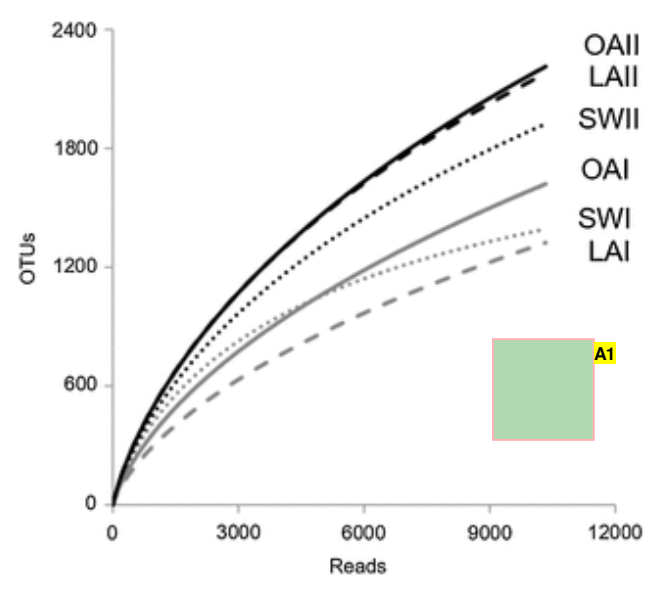

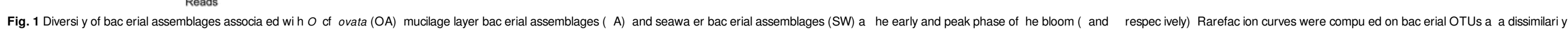
level of $3 \%$

Annotations:

A1 All figure cap ions are correc Whereas fea ures of all he ive figures are no ha ones revised and accep ed from he edi or in he las revision round Please change all he ive figures wi he accep ed ones ha you will ind in a ached

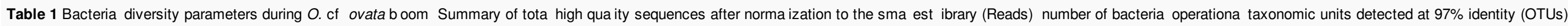

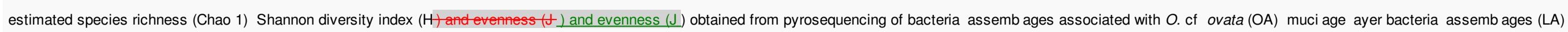
and seawater bacteria assemb ages (SW) at the ear $y$ and peak phase of the boom ( and respective $y$ )

\begin{tabular}{|c|c|c|c|c|c|}
\hline Sampe & Reads & OTUs & Chao 1 & HJOA 10 & $\underline{J}$ \\
\hline$\underline{\mathrm{OA}}$ & 10349 & 1621 & 3229 & 528 & 0715 \\
\hline $\mathrm{OA}$ & 10_349 & 2214 & 4078 & 636 & 0826 \\
\hline LA & 10_349 & 1322 & 2582 & 463 & 0644 \\
\hline LA & 10_349 & 2177 & 3886 & 631 & 0821 \\
\hline sw & 10_349 & 1394 & 1798 & 579 & 0800 \\
\hline sw & 10_349 & 1921 & 3337 & 618 & 0817 \\
\hline
\end{tabular}

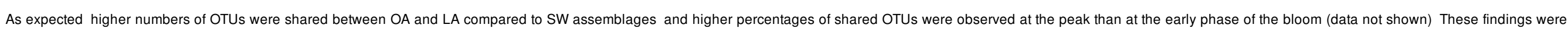

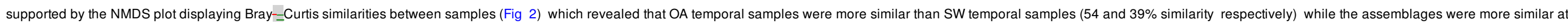

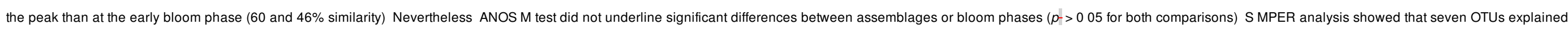

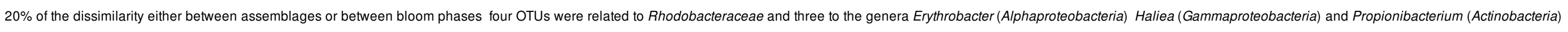
respectively (Table 2 Table S1) 


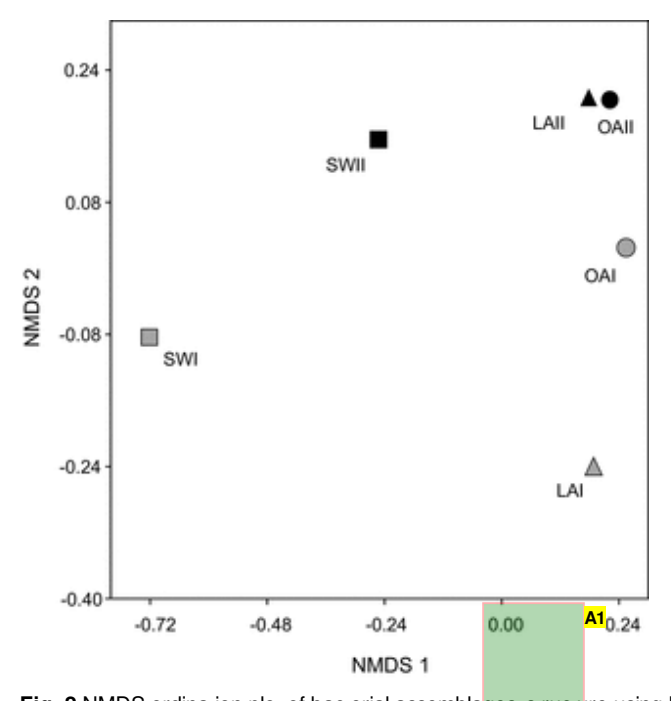

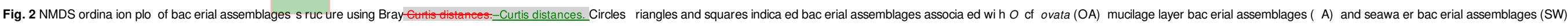
respec ively Greay and black symbols represen he early ( ) and peak ( ) phase of he bloom respec ively The plo was cons ruc ed on he basis of bac erial OTUs re rieved from pyrosequencing da a

Annotations:

A1 All figure cap ions are correc Whereas fea ures of all he ive figures are no ha ones revised and accep ed from he edi or in he las revision round Please change all he ive figures wi h he accep ed ones ha you will ind in a ached

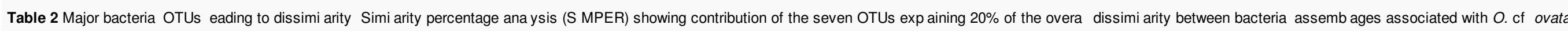

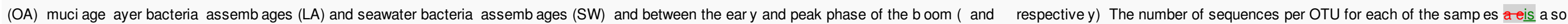
reported

\begin{tabular}{|c|c|c|c|c|c|c|c|c|c|}
\hline \multirow[t]{2}{*}{ OTU } & \multirow[t]{2}{*}{ Cosest re ative RDP $\mathrm{c}$ assifier } & \multicolumn{6}{|c|}{ No of sequences per OTU } & \multicolumn{2}{|c|}{ Contribution to dissimi arity (\%) } \\
\hline & & $\mathrm{OA}$ & $\mathrm{OA}$ & LA & LA & sw & sw & Assemb ages & B oom phases \\
\hline 6 & Ruegeria & 1519 & 462 & 2268 & 644 & 579 & 647 & 709 & 497 \\
\hline 40 & Rhodobacteraceae & 812 & 412 & 1184 & 583 & 437 & 330 & 351 & 264 \\
\hline 35 & Haliea & 568 & 9 & 638 & 10 & 23 & 48 & 283 & 286 \\
\hline 33 & Rhodobacteraceae & 13 & 20 & 13 & 32 & 692 & 49 & 222 & 337 \\
\hline 7 & Propionibacterium & 0 & 15 & 1 & 14 & 418 & 14 & 132 & 227 \\
\hline 516 & Jannaschia & 219 & 278 & 91 & 153 & 28 & 61 & 127 & 156 \\
\hline 164 & Erythrobacter & 355 & 247 & 333 & 193 & 88 & 167 & 122 & 163 \\
\hline
\end{tabular}

\section{Fable 3 Supplementary Table S1 related to this article can be found in the online version at doi 10 1016/j hal 201604003}

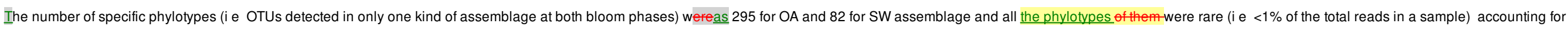
62 and $17 \%$ of the total OTUs respectively While more than half of the OA specific OTUs belonged to the Rhodobacteraceae family SW specific OTUs were more uniformly distributed between taxa (data not shown) 


\subsection{Microbial assemblages composition and comparisons}

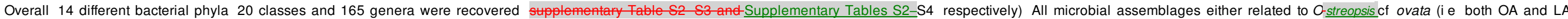

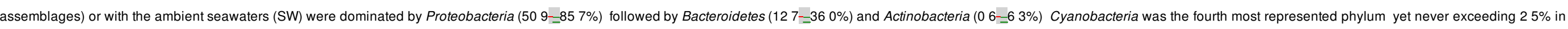

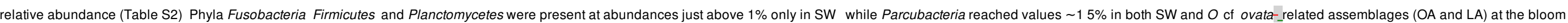
peak phase The remaining phyla Acidobacteria_Chloroflexi Chlorobi Spirochaetes TM7 and Deinococcus Thermus were rare representatives (i e $<1 \%$ Table S2)

[SS]Appendix ASupplementary dataSupplementary data associated withSupplementary Tables S2-S4 related to this article can be found in the online version at doi 10 1016/j hal 2016 04 003

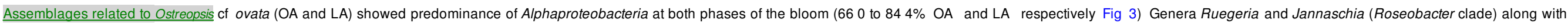

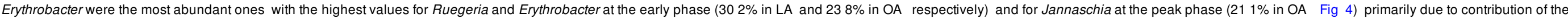

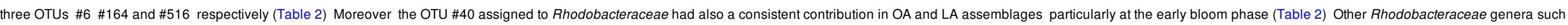

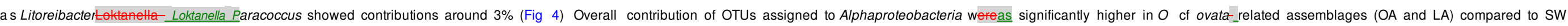

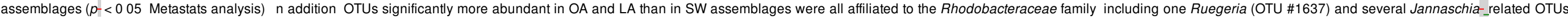

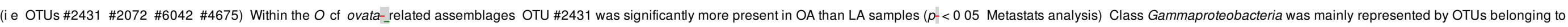

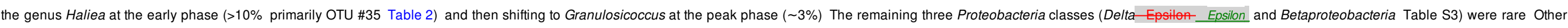

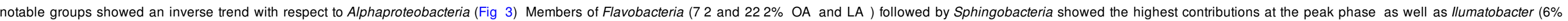
Actinobacteria) 3)

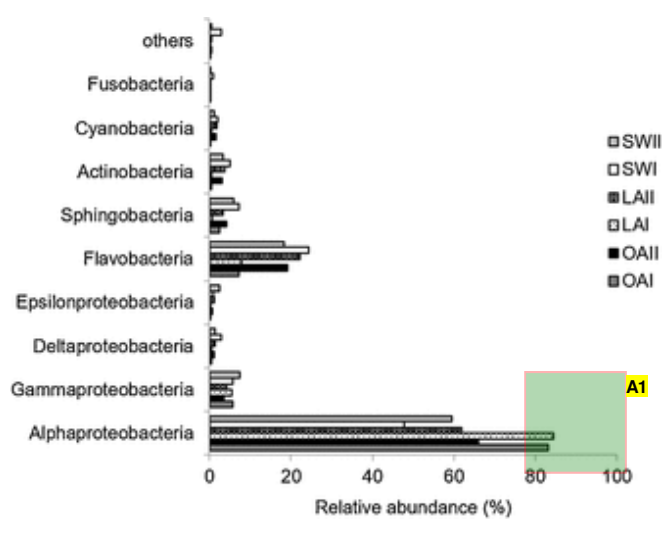

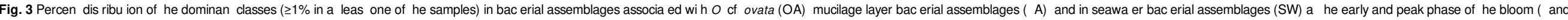

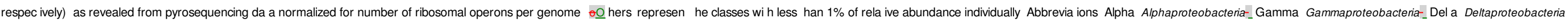

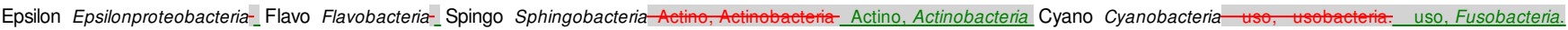

Annotations:

A1 All figure cap ions are correc Whereas fea ures of all he ive figures are no ha ones revised and accep ed from he edi or in he las revision round Please change all he ive figures wi h he accep ed ones ha you will ind in a ached 


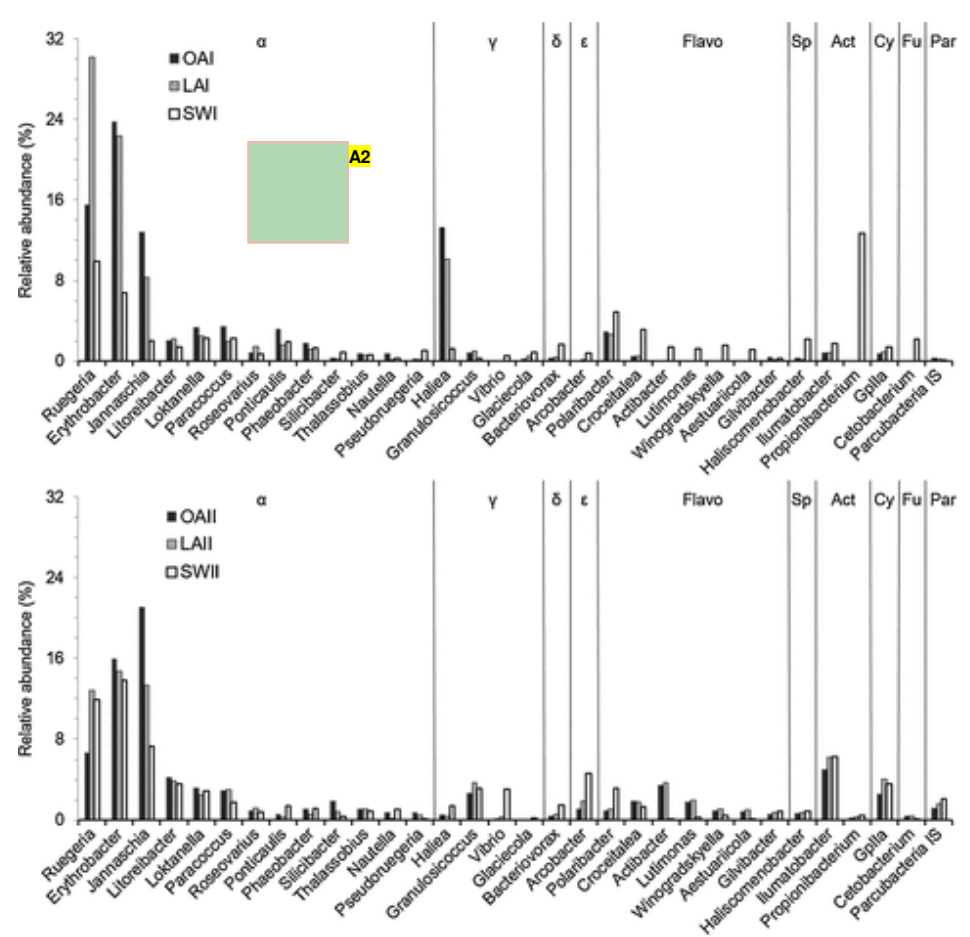

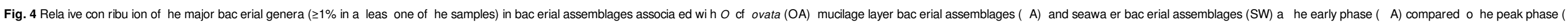

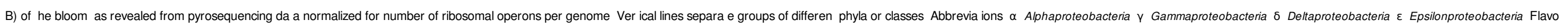
Flavobacteria SpSphing Act, Sphingobacteria Act, Actinobacteria Cy Cyanobacteria Fu Fusobacteria Par Parcubacteria S Incertae Sedis

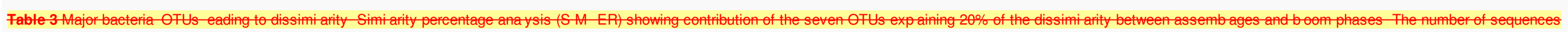
per OTU for each of the samp es areis a so reported (Tab e 3 does not exist in the manuscript $P$ ease remove comp ete y Tab e 3 and the re ative egend from the artic e ) at text: Fabe 3

\begin{tabular}{|c|c|c|c|c|c|c|c|c|c|}
\hline \multirow[t]{2}{*}{ ӨTU(Table 3 does not exist in the manuscript Please remove completely Table 3 and the relative legend from the article ) } & \multirow[t]{2}{*}{ Gosest reative RD e assifier } & \multicolumn{6}{|c|}{ No of sequenees per OTU } & \multicolumn{2}{|c|}{ Gontribution to dissimi arity (\%) } \\
\hline & & $\mathrm{OA}$ & $\mathrm{OA}$ & LA & LA & SW & SW & Assemb ages & B oom phases \\
\hline 6 & fituegeria & 1519 & 462 & 2268 & 644 & 579 & 647 & 709 & 497 \\
\hline 40 & Ahodobacteracea & 812 & 412 & 1184 & 583 & 437 & 330 & 351 & 264 \\
\hline 35 & Haliea & 568 & 9 & 638 & 10 & 23 & 48 & 283 & 286 \\
\hline 33 & Fhodocteraceas & 13 & 20 & 13 & 32 & 692 & 49 & 222 & 337 \\
\hline 7 & Propionibacterium & 0 & 15 & 1 & 14 & 418 & 14 & 132 & 227 \\
\hline 516 & Jannaschia & 219 & 278 & 91 & 153 & 28 & 61 & 127 & 156 \\
\hline 164 & Erythroeter & 355 & 247 & 333 & 193 & 88 & 167 & 122 & 163 \\
\hline
\end{tabular}

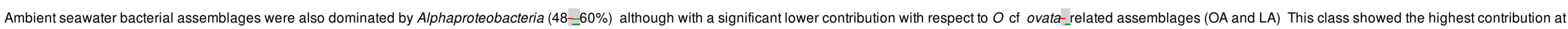




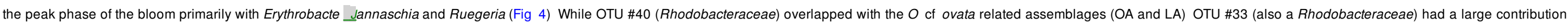

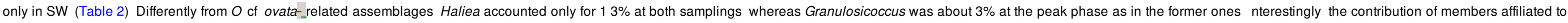

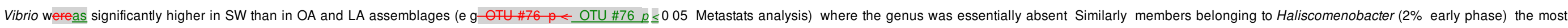

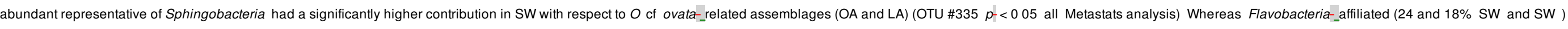

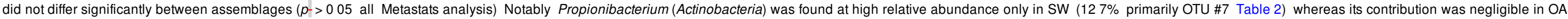
and LA assemblages A similar pattern was also observed for Cetobacterium (Fusobacteria Fig 4)

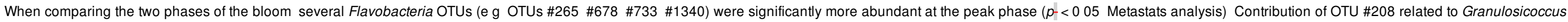

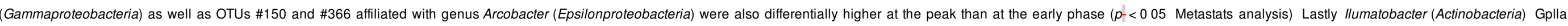

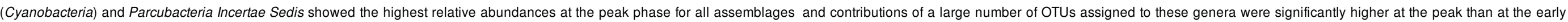
phase of the bloom ( $p_{-}<005$ Metastats analysis) Fig 5 summarizes bacterial assemblages' main shifts in relative abundance at genus level between early and peak phase of the bloom

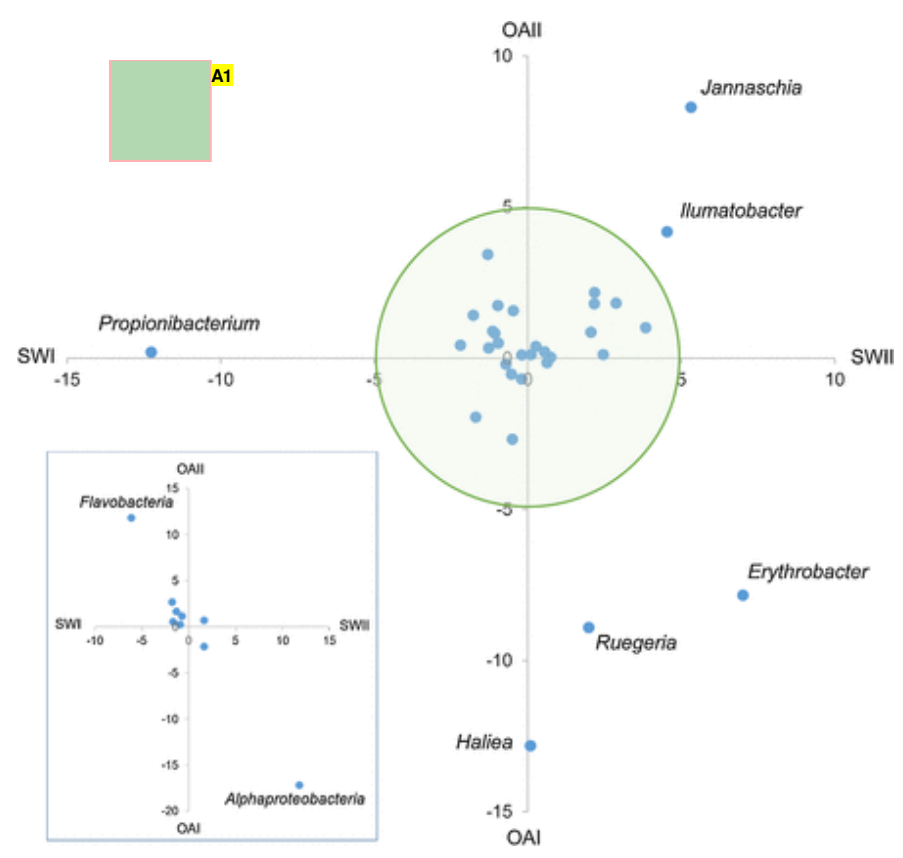

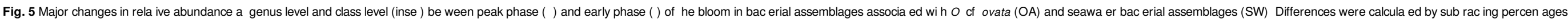
recorded a he peak from values a he early phase of he bloom The posi ive values deno e higher con ribu ion a he peak as opposed o he early phase

\section{Annotations:}

A1 All figure cap ions are correc Whereas fea ures of all he ive figures are no ha ones revised and accep ed from he edi or in he las revision round Please change all he ive figures wi h he accep ed ones ha you will ind in a ached

\section{Discussion}

\subsection{General}

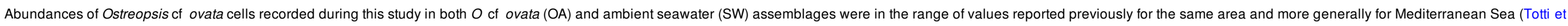

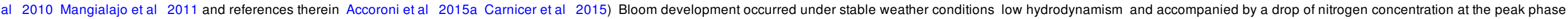

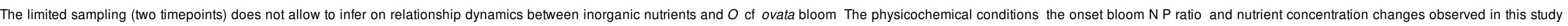




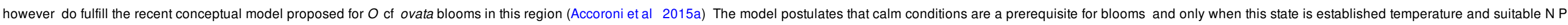

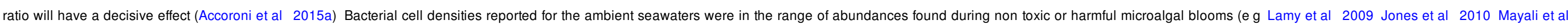
2011 Park et al 2015)

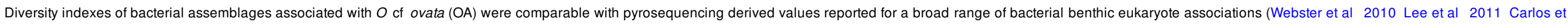

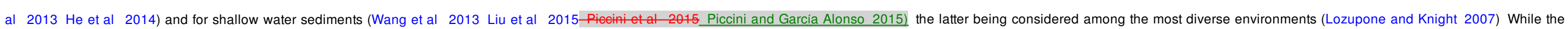
rarefaction curves indicated that species richness was not fully sampled they do suggest a higher bacterial richness at the peak than at the early phase of the bloom in accordance with Chao1 and Shannon estimators

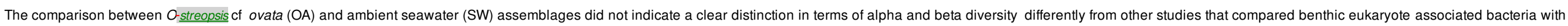

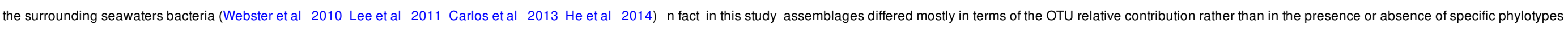

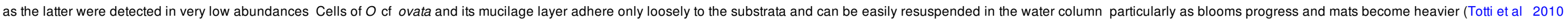

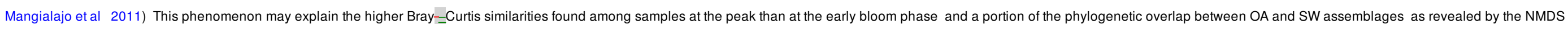
plot

\subsection{Bacterial assemblages associated with 0 . ef. ovataO. cf. ovata}

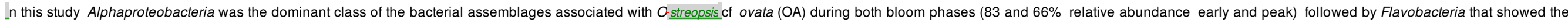

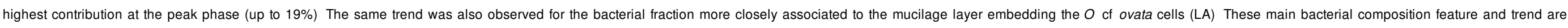

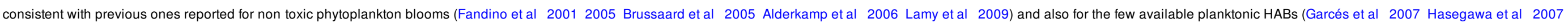
Jones et al 2010 Park et al 2015) with the exception for Yang et al (2012 2015)

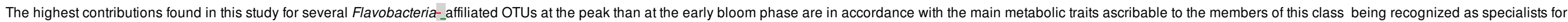

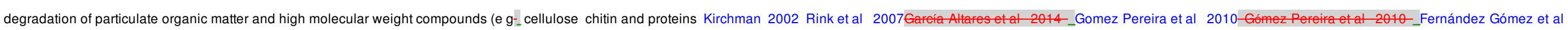

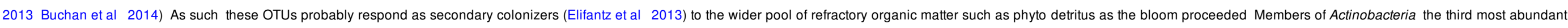

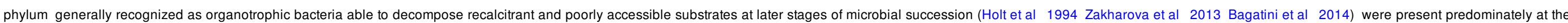

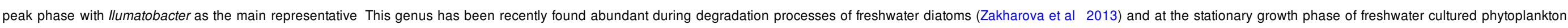

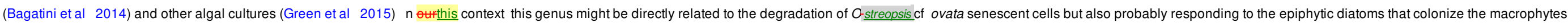

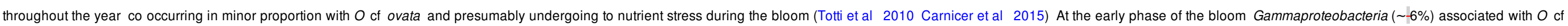

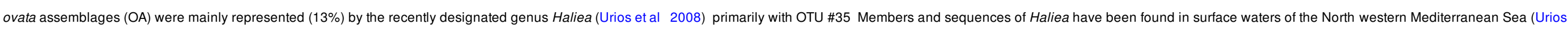

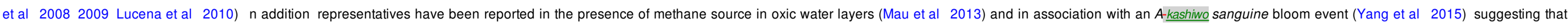

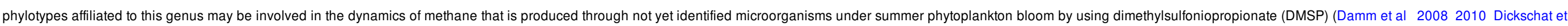

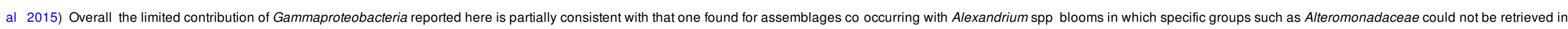

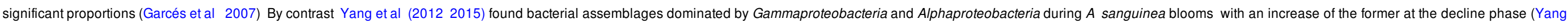

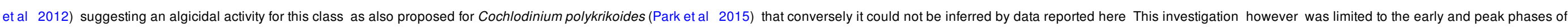

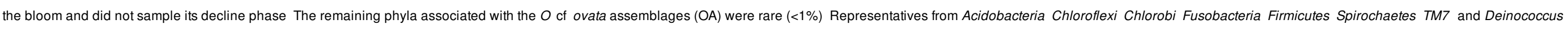
Thermus were observed While their relative abundances were low it cannot be precluded their importance in the nutrient dynamics and interactions within the assemblages

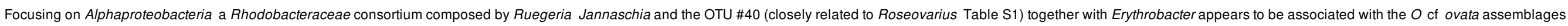

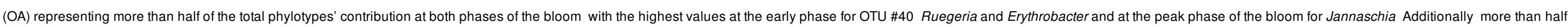

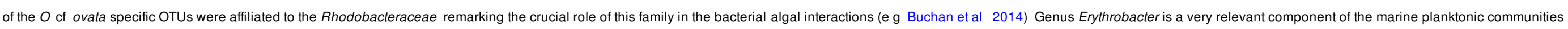

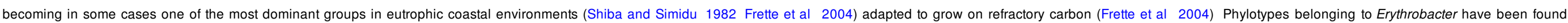

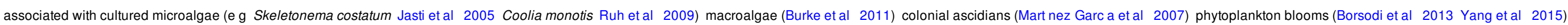




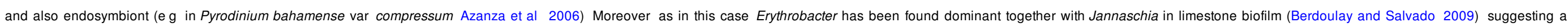
potential relationship between these two aerobic anoxygenic phototrophic (AAnP) genera

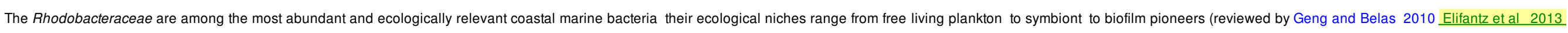

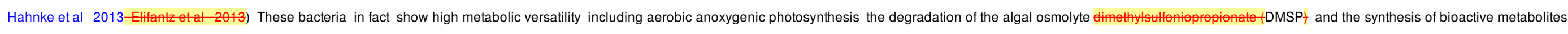

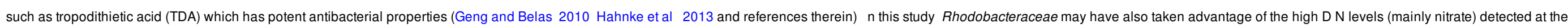

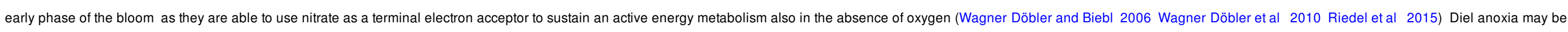

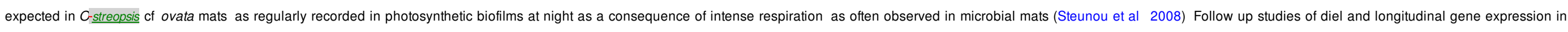

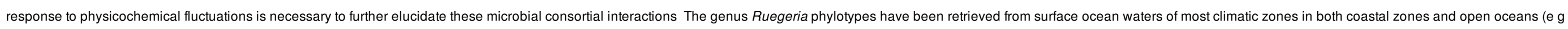

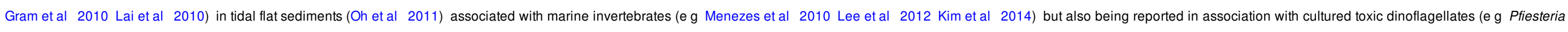

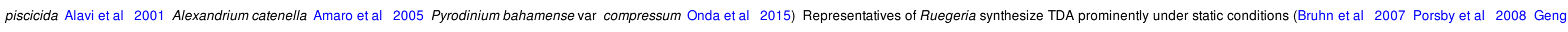

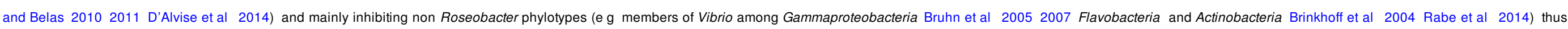

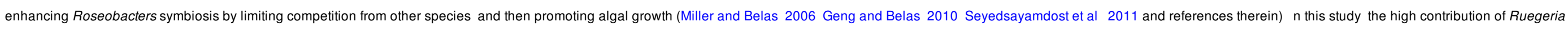

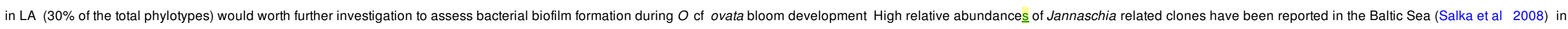

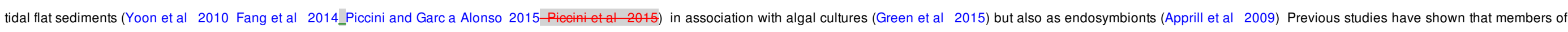

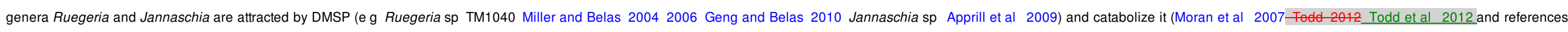

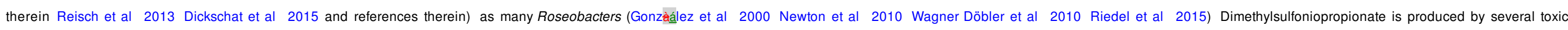
dinoflagellates (reviewed by Caruana and Malin 2014) including $O$ cf ovata (Vanucci et al in press)

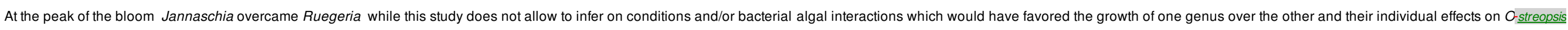

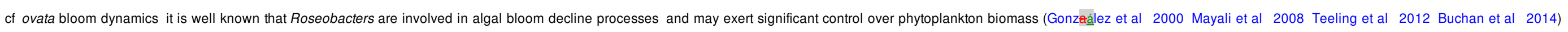

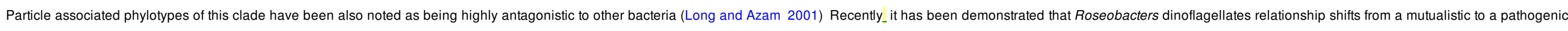

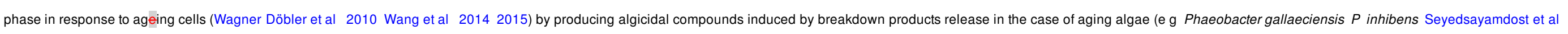

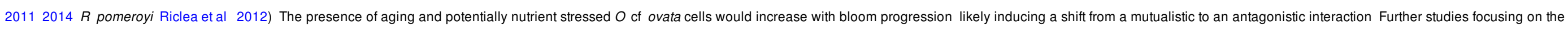
potential transition from mutualistic to antagonistic interactions between $O$ cf ovata and the associated Roseobacters are needed

\subsection{Bacterial assemblages in ambient seawaters}

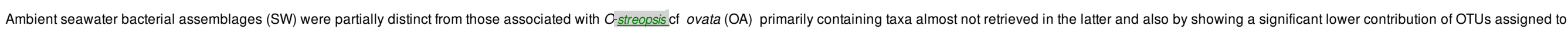

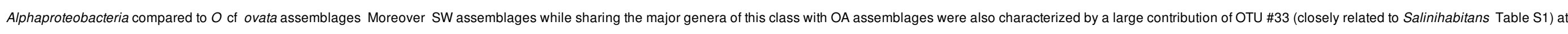

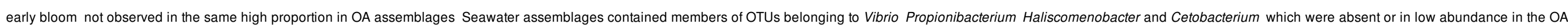

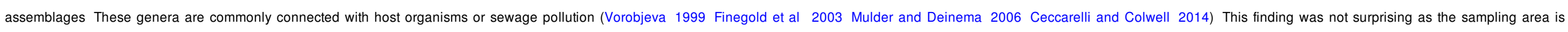

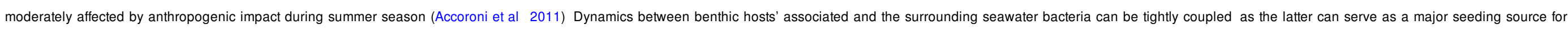

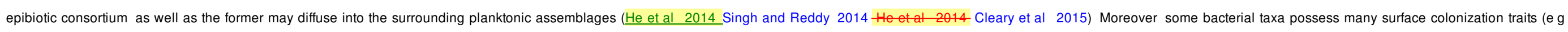

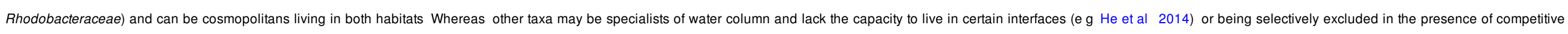

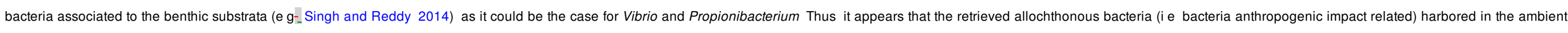

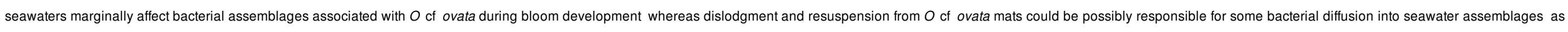
also suggested by similarities pattern between samples in the NMDS plot

\section{Conclusions}

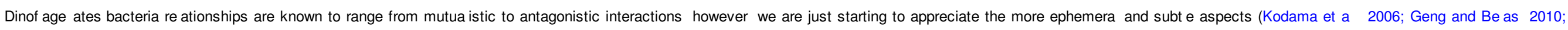




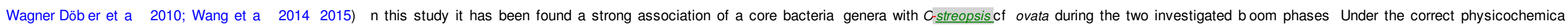

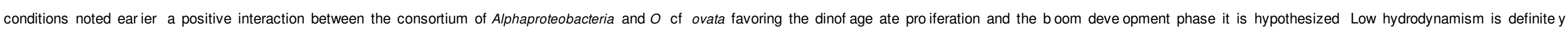

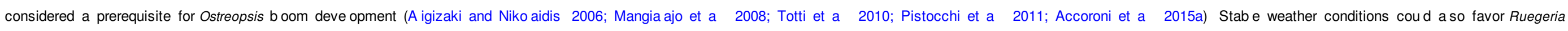

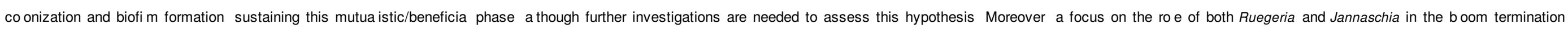

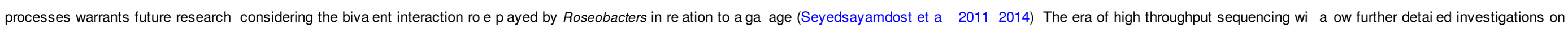
bacteria co occurring with epiphytic/benthic harmfu a ga booms at the consortia and ce ce eves and their interactions

\section{and Todd et al., 2012.Acknowledgements}

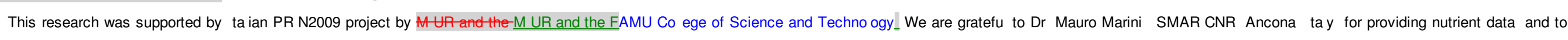
Natasha Butz Microbiome Core Faci ity UNC Chape Hi Nerth Garo inaC USA for technica assistance in sequencing Appendix ASupp ementary dataThe fo owing are the supp ementary data to this artic e:[SS]

\section{References}

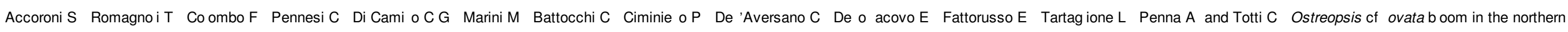

Adriatic Sea during summer 2009: Eẹco ogy mo ecu ar characterization and toxin profie Mar Pol ut Bull 62201125122519

Accoroni S Romagno i T Pichierri S Co ombo F and Totti C Morphometric anaysis of Ostreopsis cf ovata ce s in re ation to environmenta conditions and boom phases Harmful Algae 1920121522

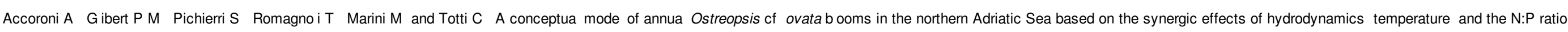

of water co umn nutrients Harmful Algae 45 2015a 1425

Accoroni S Percopo Cerino F Romagno i T Pichierri S Perrone C and Totti C A e opathic interactions between the HAB dinof age ate Ostreopsis cf ovata and macroa gae Harmful Algae $492015 \mathrm{~b} 147155$

A avi M Mi er T Erandson K Schneider R and Be as R Bacteria community associated with Pfiesteria-ike dinofage ate cuturesEnvike dinof age ate cu tures Environ Microbiol 32001380396

A derkamp A C Sintes E and Hernd G J Abundance and activity of major groups of prokaryotic pankton in the coasta North Sea during spring and summer Aquat Microb Ecol 452006237246

A igizaki K and Niko aidis G The presence of the potentia y toxic genera Ostreopsis and Coolia (Dinophyceae) in the north Aegean Sea Greece Harmful Algae 52006717730

A igizaki K Katikou P Mi andri A and Diogene J Occurrence of paytoxin-group toxins in seafood and future strategies to comp ement the present state of the art Toxicon 572011390399

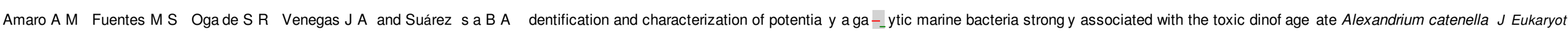
Microbiol 522005191200

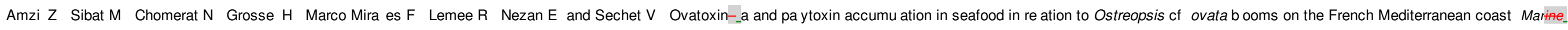

Drugs 102012477496

Appri A Mar ow HQ Martinda e M Q and Rappe M S The onset of microbia associations in the cora Pocillopora meandrina ISMEJ 32009685699

Azanza M P Azanza R V Vargas V M and Hedreyda C T Bacteria endosymbionts of Pyrodinium bahamense var compressum Microb Ecol 522006756764

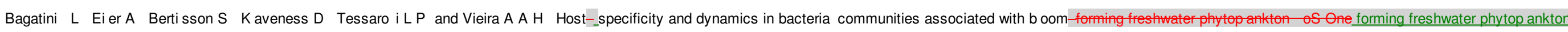
PLOS ONE 92014 e85950

Berdou ay M and Sa vado J C Genetic characterization of microbia communities iving at the surface of bui ding stones Lett Appl Microbiol 492009311316

Bo ch C J S and Subramanian T A The toxic dinof age ate Gymnodinium catenatum (Dinophyceae) requires marine bacteria for growth J Phycol 47201110091022

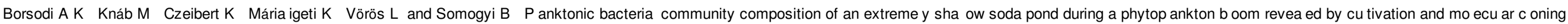


Extremophiles 172013575584

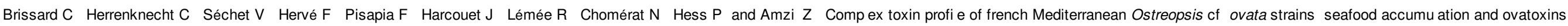
prepurification Mar Drugs 12201428512876

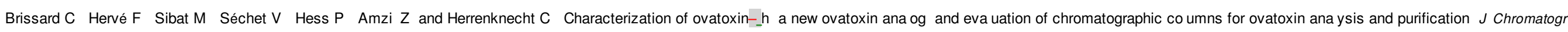
A 1388201587101

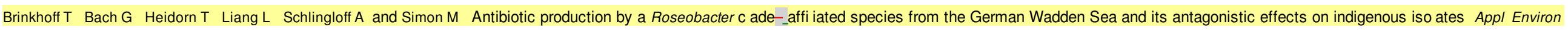
Microbiol 7020042560 2565(For a phabe ca order, h s reference shou d precede he wo above ones )

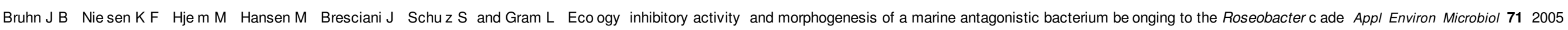
72637270

Bruhn J B Gram L and Beas R Production of antibacteria compounds and biofi m formation by Reseobacte species are inf uenced by cu ture conditions Appl Environ Microbiol 732007442450

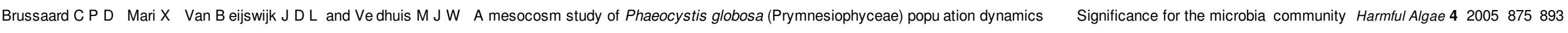
Buchan A Lec eir G R Gu vik C A and Gonzá ez J M Master recyc ers: features and functions of bacteria associated with phytop ankton b ooms Nature Publishing Publ Group 122014686698

Burke C Thomas T Lewis M Steinberg P and Kje eberg S Composition uniqueness and variabi ity of the epiphytic bacteria community of the green a ga Ulva australis ISME J 52011590600

Car os C Torres T T and Ottoboni L M M Bacteria communities and species-_specific associations with the mucus of Brazi ian cora species Sci Rep 320131624

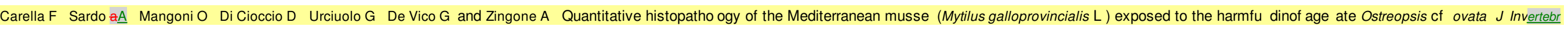
Pathol 1272015130 140(Th s reference shou d precede he one above)

Carnicer O Gua ar C Andree K B Diogène J and Fernández Tejedor M Ostreopsis cf ovata dynamics in the NW Mediterranean Sea in re ation to biotic and abiotic factors Environ Res 14320158999

Carreira C Pie T Staa M Stuut J B W Midde boe M and Brussaard C P D Microsca e spatia distributions of microbes and viruses in intertida photosynthetic microbia mats Springerplus 42015239

Caruana A M N and Ma in G The variabi ity in DMSP content and DMSP yase activity in marine dinof age ates Prog Oceanogr 1202014410424

Ceccare i D and Co we R R Vibrio eco ogy pathogenesis and evo ution Front Microbiol 52014256

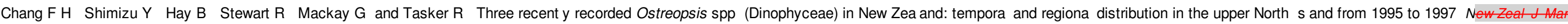
Frosh_Z J Mar Freshw 3420002939

Ciminie o P De 'Aversano C De o acovo E Fattorusso E Forino M and Tartag ione L LC MS of pa ytoxin and its ana ogues: state of the art and future perspectives Toxicon 572011376389

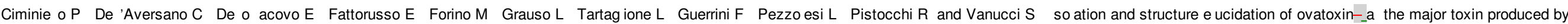

Ostreopsis ovata J Am Chem Soc $1342012 a 18691875$

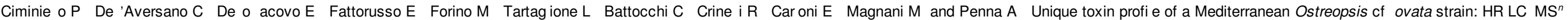
characterization of ovatoxin-f a new pa ytoxin congener Chem Res Toxicol $252012 \mathrm{~b} 12431252$

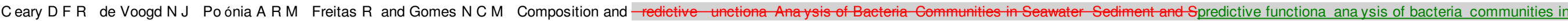
seawater sediment and sponges in the Spermonde Archipe ago-ndonesia-_ndonesia Microb Ecol 70 (4) 2015889903

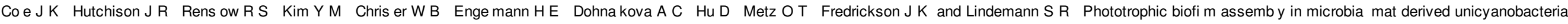
consortia: Hode systems for the study of autotroph-mode systems for the study of autotroph heterotroph interactions Front Microbiol $52014 a 118$ 


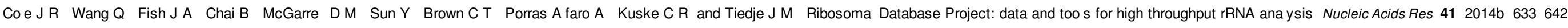

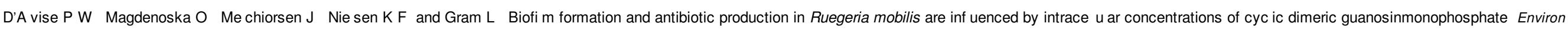
Microbiol 16201412521266

Damm E Kiene R R Schwarz J Fack E and Dieckmann G Methane cyc ing in Arctic shef water and its re ationship with phytop ankton biomass and DMSP Mar Chem 10920084559

Damm E He mke E Thoms S Schauer U Nöthig E Bakker K and Kiene R P Methane production in aerobic o igotrophic surface water in the centra Arctic Ocean Biogeosciences 7201010991108

Dickschat J S Rabe P and Citron C A The chemica bio ogy of dimethy su foniopropionate Org Biomol Chem 13201519541968

Donovan C J Garduno R A Ka mokoff M Ku J C Qui iam M A and Gi T A Pseudoalteromonas bacteria are capab e of degrading para ytic she fish toxins Appl Environ Microbiol 75200969196923

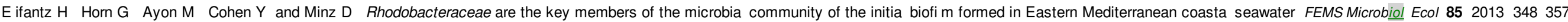

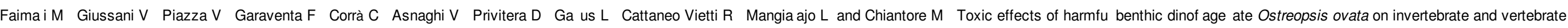
marine organisms Mar Environ Res 76201297107

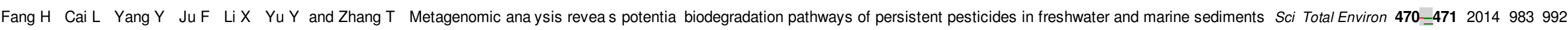

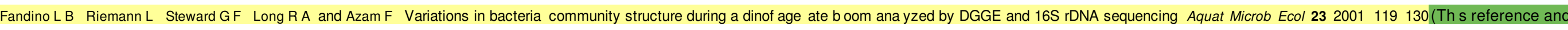

\section{ha one be ow (e Fand no e a ,2005) shoud precede he one above (e Fang e a ,2014))}

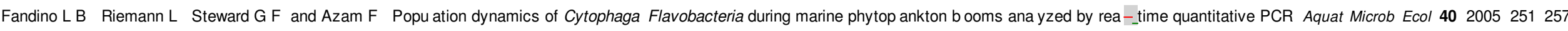
Fernández Gómez B Richter M Schü er M Pinhassi J Acinas S G Gonzá ez J M and Pedrós A ió C Eco ogy of marine Bacteroidetes: a comparative genomics approach ISME J 7201310261037

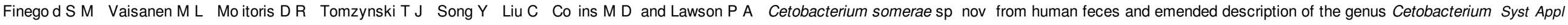
Microbiol 262003177181

Frette L Johnsen K Jørgensen N O G Nybroe O and Kroer N Functiona characteristics of cu turab e bacteriop ankton from marine and estuarine environments Int Microbiol 72004219227

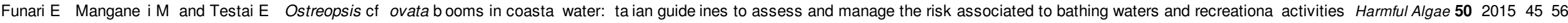

Fur an M Antonio i M Zingone A Sardo A B ason C Pa avicini A and Fonda Umani S Mo ecuar identification of Ostreopsis cf ovata in fi ter feeders and putative predators Harmful Algae 2120132029

Ga ite i M Ungaro N Addante LM Procacci V Si veri NG and Sabbà C Respiratory i ness as a reaction to tropica a ga b ooms occurring in a temperate c imate $J$ Amer Med Assoc 293200525992600

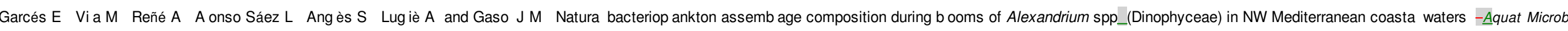
Ecol 4620075570

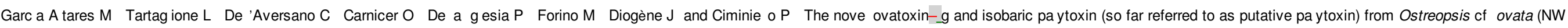

Mediterranean Sea): structura insights by LC-_high reso ution MSn Anal Bioanal Chem 407201411911204

Geng $\mathrm{H}$ and Be as R Mo ecu ar mechanisms under ying roseobacte - phytop ankton symbioses Curr Opin Biotechnol 212010332338

Geng $\mathrm{H}$ and $\mathrm{Be}$ as $\mathrm{R}$ TdaA regu ates tropodithietic acid synthesis by binding to the tdaC promoter region $J$ Bacteriol 193201140024005

Gomez Pereira P R Fuchs B M A onso C O iver M J Van Beusekom J E and Amann R Distinct f avobacteria communities in contrasting water masses of the North At antic Ocean ISME J 42010472487

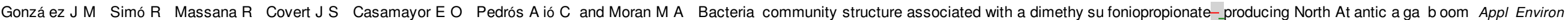

Microbiol 66200042374246 


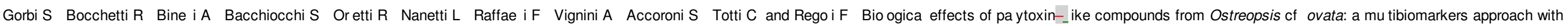
musse s Mytilus galloprovincialis Chemosphere 892012623632

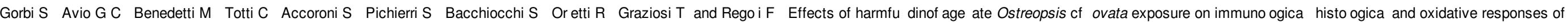
musse s Mytilus galloprovincialis Fish Shellfish Immun 352013941950

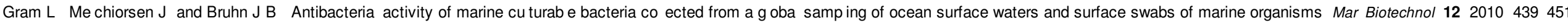

Grané i E Vidyarathna N K Funari E Cumaranatunga P R T and Scenati R Can increases in temperature stimu ate b ooms of the toxic benthic dinof age ate Ostreopsis ovata? Harmful Algae 102011165172 Green D H Hart M C B ackburn S and Bo ch C J S Bacteria diversity of Gymnodinium catenatum and its re ationship to dinof age ate toxicity Aquat Microb Ecol 6120107387

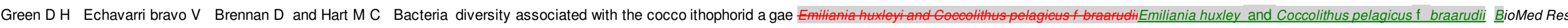
Int 20152015194540

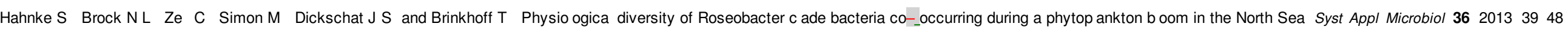
Hammer $\varnothing$ Harper D A T and Ryan P D PAST: -pa eonto ogica statistics software package for education and data ana ysis Palaeontol Electron 420019

Hasegawa Y Martin J L Giewat M W and Rooney Varga J N Microbia community diversity in the phycosphere of natura popu ations of the toxic a ga Alexandrium fundyense Environ Microbiol 9200731083121 Has e G R The inverted microscope method n: Sournia A (Ed) Phytoplankton Manual Monographs on Oceanographic Methodology vol. 61978 UNESCO Paris 8896

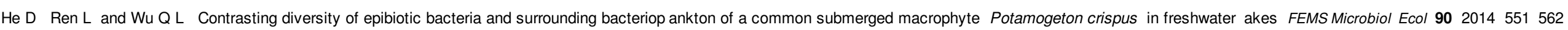

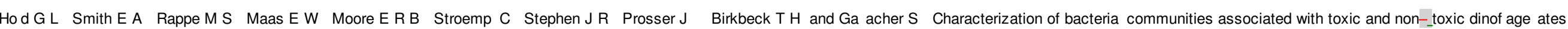

Alexandrium spp and Scrippsiella trochoidea FEMS Microbiol Ecol 372001161173 Hot JG Krieg NR Seath PHA Sta ey J T and Wi iams S T Bergey's mantua of determinative bManua of Determinative Bacterio ogy 9 th ed 1994 Wi iams \& Wikins Ba timore 804p

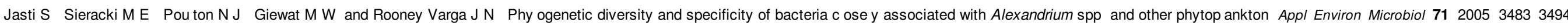

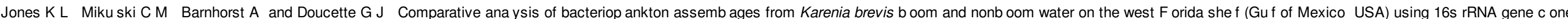
ibraries FEMS Microbiol Ecol 732010468485

Kermarec F Dor F Armengaud A Char et F Kantin R Sauzade D and De Haro L Hea th risks re ated to Ostreopsis ovata in recreationa waters Environment Risques \& Risques Santé 72008357363

Kim Y Park S Nam B Jung Y Kim D and Yoon J Ruegeria meonggeisp nov an a phaproteobacterium iso ated from ascidian Halocynthia roretzi Antonie van Leeuwenhoek 1052014551558 Kirchman D L The eco ogy of Cytophaga Flavobacteria in aquatic environments FEMS Microbiol Ecol 39200291100

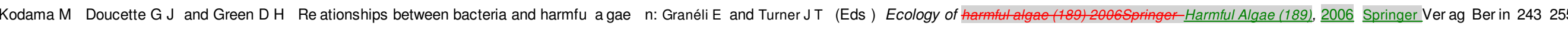

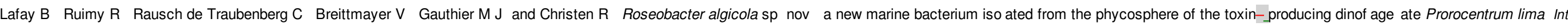
J Syst Evol Microbiol 451995290296

Lai Q L Yuan J LiFY Zheng T L and Shao ZZ Ruegeria pelagia is a ater heterotypic synonym of Ruegeria mobilis Int J Syst Evol Microbiol 60201019181920

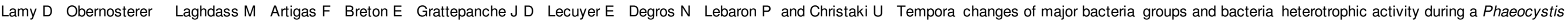
globosa boom in the eastern Eng ish Channe Aquat Microb Ecol 58200995107

Lee O O Wang Y Yang J Lafi F F A Suwai em A and Qian P Pyrosequencing revea s high y diverse and species_-specific microbia communities in sponges from the Red Sea ISME J 52011650664 


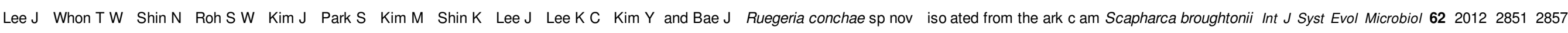

Liu J Liu X Wang M Qiao Y Zheng Y and Zhang X H Bacteria and archaea communities in sediments of the North Chinese Margina Seas Microb Ecol 702015105117

Long R A and Azam F Antagonistic interactions among marine pe agic bacteria Appl Environ Microbiol 67200149754983

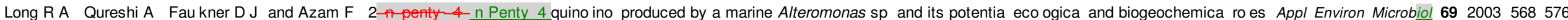

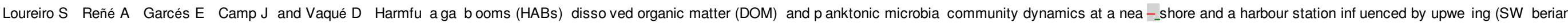

Peninsu a) J Sea Res 652011401413

Lozupone C A and Knight R Goba patterns in bacteria diversity PNAS 10420071143611440

Lucena T Pascua J Garay E Araha DR Macián M C and Puja te M J Haliea mediterranea sp nov a marine gammaproteobacterium Int J Syst Evol Microbiol 60201018441848

Mabrouk L Hamza A Ben Brahim M and Bradai M N Tempora and depth distribution of microepiphytes on Posidonia oceanica (L) De ie eaves in a meadow off Tunisia Mar Ecol Evol Persp 322011148161

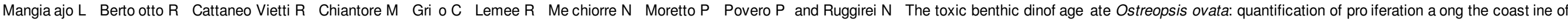
Genoatay Mar O tay Mar Pollut Bull 56200812091214

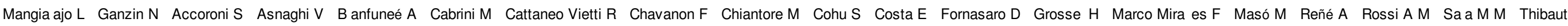

T Totti C ViaM and Lemé R Trends in Ostreopsis pro iferation a ong the Northern Mediterranean coasts Toxicon 572011408420

Marini M Fornasiero P and Artegiani A Variations of hydrochemica features in the coasta waters of Monte Conero: 1982-_1990 PS ZN Mar Ecol 232002258271

Mart nez Garc a M D az Va dés M Wanner G Ramos Espá A and Antón J Microbia community associated with the co onia ascidian Cystodytes dellechiajei Environ Microbiol 92007521534

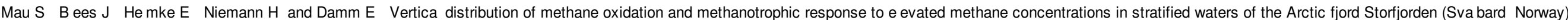

Biogeosciences 10201362676278

Maya i X and Azam F A gicida bacteria in the sea and their impact on a ga b ooms J Eukaryot Microbiol 512004139144

Maya i X Franks P J S Tanaka Y and Azam F Bacteria_-_induced moti ity reduction in Lingulodinium polyedrum J Phycol 442008923928

Maya i X Franks P J S and Burton R S Tempora attachment dynamics by distinct bacteria taxa during a dinof age ate boom Aquat Microb Ecol 632011111122

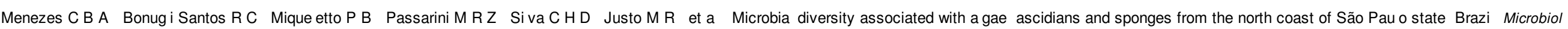

Res 1652010466482

Mi er T R and Be as R Dimethy su foniopropionate metabo ism by Pfiesteria associated Roseobacter sppAppl EnvPfiesteria associated Roseobacter spp Appl Environ Microbiol 70200433833391

Mi er T R and Be as R Moti ity is invo ved in Silicibactersp TM1040 interaction with dinof age ates Environ Microbiol 8200616481659

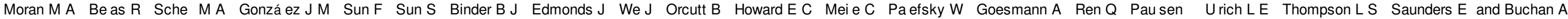

Eco ogica genomics of marine roseobacters Appl Env Mierobiron Microbiol 73200745594569

Mu der E G and Deinema M H The genus Haliscomenobacter Prokariotes 72006602604

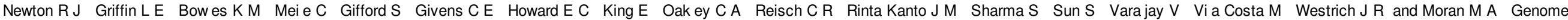

characteristics of a genera ist marine bacteria ineage ISMEJ 42010784798

Oh K H Jung Y T Oh T K and Yoon J H Rutregria faecimarisRuegeria faecimaris sp nov iso ated from a tida fat sediment Int J Syst Evol Microbiol 61201111821188 


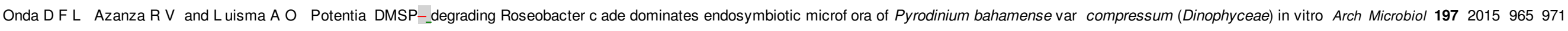

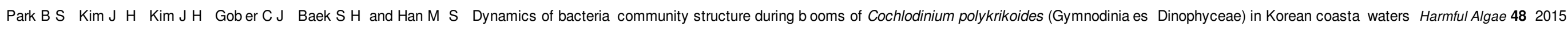
4454

Pérez Guzmán L Perez Matos A E Rosado W Tosteson T R and Govind N S Bacteria associated with toxic c ona cu tures of the dinof age ate Ostreopsis lenticularis Mar Biotechnol 102008492496

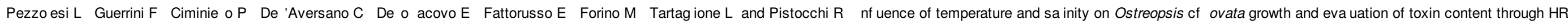
LC MS and bio ogica assays Water Res 4620128292

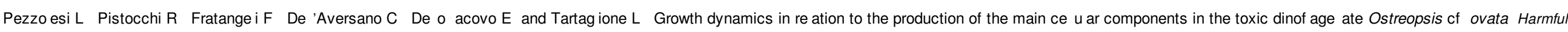
Algae 362014110

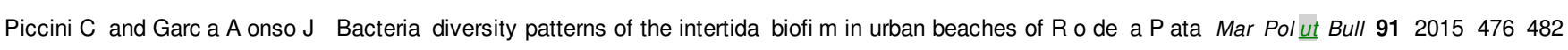

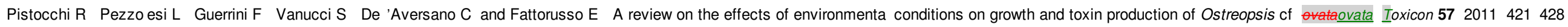

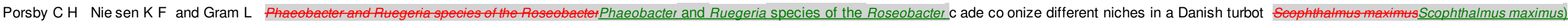
rearing farm and antagonize turbot arva pathogens under different growth conditions Appl Environ Microbiol 74200823562364

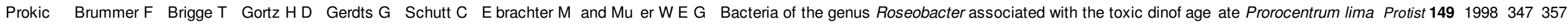
Rabe P K apschinski T Brock N L Citron C D’A vise P Gram L and Dickschat J S Synthesis and bioactivity of ana ogues of the marine antibiotic tropodithietic acid Beilstein J Org Chem 10201417961801 Reisch C R Crabb W M Gifford S M Teng Q Stoudemayer M J Moran M A and Whitman W B Metabo ism of dimethy su phoniopropionate by Ruegeria pomeroyi DSS-3 Mol Microbiol 892013774791 Ric ea R Geitzmann J Bruns H Junker C Schuz B and Dickschat J S A gicida actones from the marine Roseobacterc ade bacterium Ruegeria pomeroyi Beilstein J Org Chem 82012941950

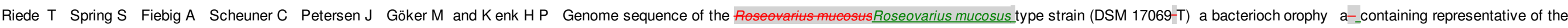
marine Roseobacter group iso ated from the dinof age ate Alexandrium ostenfeldi-Alexandrium ostenfeldii S Stand Genomic Sci 10201517

Rink B Seeberger S Martens T Duerse en C D Simon M and Brinkhoff T Effects of phytop ankton b oom in a coasta ecosystem on the composition of bacteria communities Aquat Microb Ecol 4820074760

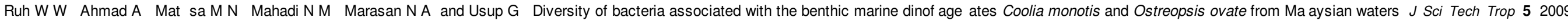
2333

Sakami T Nakahara H Chinain M and shida Y Effects of epiphytic bacteria on the growth of the toxic dinof age ate Gambierdiscus toxicus (Dinophyceae) J Exp Mar Biol Ecol 2331999231246

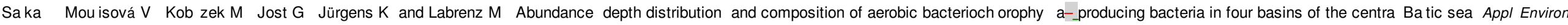
Microbiol 74200843984404

Santos M A G and Azanza R V Responses of Pyrodinium bahamense var compressum and associated cu tivab e bacteria to antibiotic treatment J Appl Phycol 242012825835

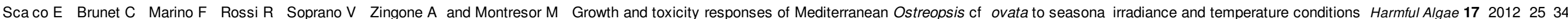
Seyedsayamdost M R Case R J Ko ter R and C ardy J The Jeky -and-and Hyde chemistry of Phaeobacter gallaeciensis Nat Chem 32011331335

Seyedsayamdost M R Wang R Koter R and C ardy J Hybrid biosynthesis of roseobacticides from a ga and bacteria precursor mo ecu es J Amer Chem Soc 13620141515015153

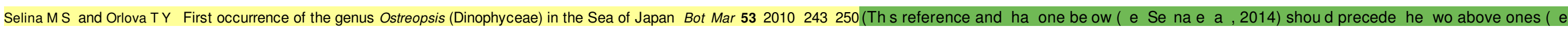

Seyedsayamdos e a ,2011 and Seyedsayamdos e a ,2014)) 


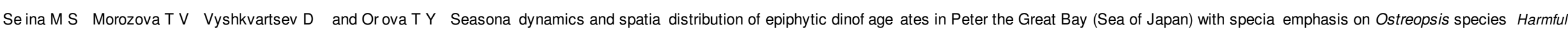
Algae 322014110

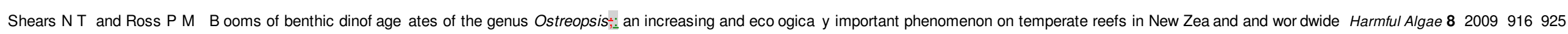
Shiba T and Simidu U Erythrobacter longus gen nov sp nov an aerobic bacterium which contains bacterioch orophy a Int J Syst Bacteriol 321982211217

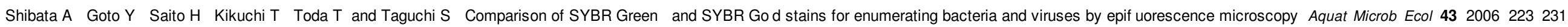
S ightom R N and Buchan A Surface co onization by marine roseobacters: -integrating genotype and phenotype Appl Environ Microbiol 75200960276037

Singh R P and Reddy CRK Seaweed microbia interactions: key functions of seaweed associated bacteria FEMS Microbiol Ecol 882014213230 (Th s reference shou d precede he one above)

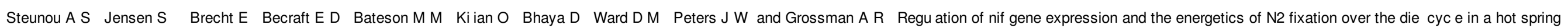
microbia mat ISMEJ 22008364378

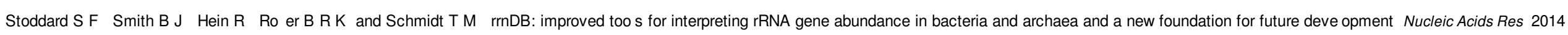
http://dx doi org/10 1093/nar/gku1201

Strick and J D H and Parsons TR A practica handbook of seawater anaysis J Fish Res Board Can 1671972310

Su J Q YuZM Tian Y Song XX Hong HS and Zheng TL Bio ogica activity of a red-_tide a ga A tamarense under co-_cu tured condition with bacteria J Environ Sc-_China 17200510471050

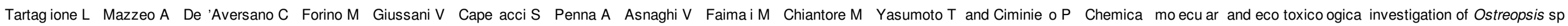
from Cyprus s and: structura insights into four new ovatoxins by LC HRMS/MS Anal Bioanal Chem 4082016915932

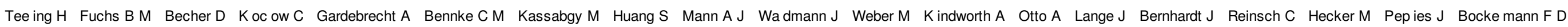

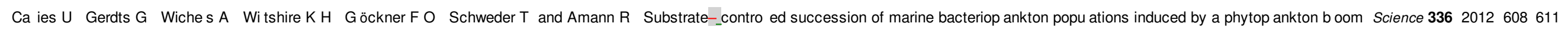

Throndsen J Preservation and storage n: Sournia A (Ed) Phytoplankton Manual. Monographs on Oceanographic Methodology 6, 1978 UNESCO Paris 6974

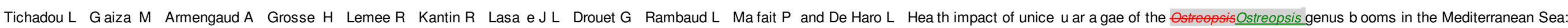
experience of the French Mediterranean coast survei ance network from 2006 to 2009 Clin Toxicol 482010839844

Todd J D Kirkwood M Newton Payne S and Johnston A W DddW a third DMSP yase in a mode Roseobacter marine bacterium Ruegeria pomeroyi DSS-_3 ISME J 62012223226

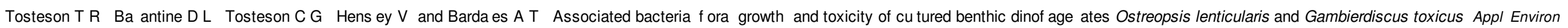
Microbiol 551989137141

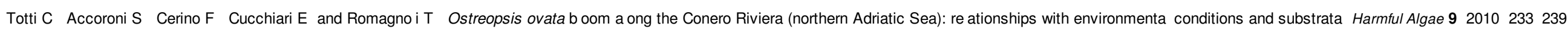

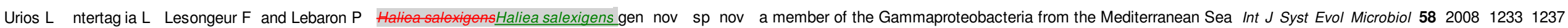
Urios L ntertagia L Lesongeur F and Lebaron P HaliearubraHaliea rubrasp nov a member of the Gammaproteobacteria from the Mediterranean Sea Int J Syst Evol Mict Evol Microbiol 59200911881192

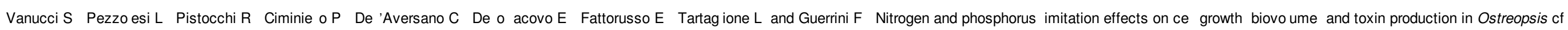
ovata Harmful Algae 15 2012a 7890

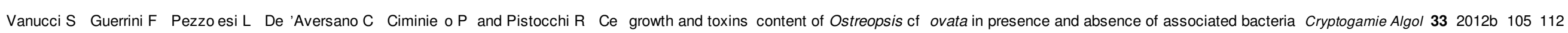

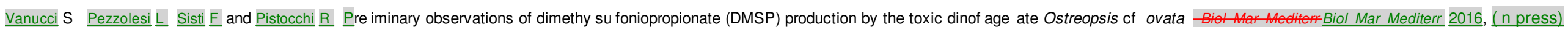


Vi a M Garcés E and Masó M Potentia y toxic epiphytic dinof age ate assemb ages on macroa gae in the NW Mediterranean Aquat Microb Ecol 2620015160

Vorobjeva L Propionibacteria 1999 K uwer aeademic publDordrecht Boston-Academic Publ Dordrecht/Boston/London

Wagner Döb er and Bieb H Environmenta bio ogy of the marine Roseobacter ineage Annu Rev Microbiol 602006255280

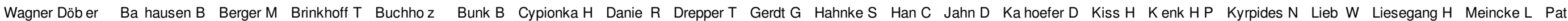

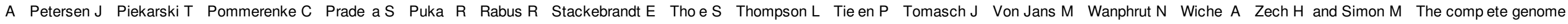
sequence of the a ga symbiont Dinoroseobacter shibae: a hitchhiker's guide to ife in the sea ISMEJ 420106177

Wang Q Garrity G M Tiedje J M and Co e J R Naïve Bayesian C assifier for rapid assignment of rRNA sequences into the new bacteria taxonomy Appl Environ Microbiol 73200752615267

Wang B X Zhou Y Y Bai S J Su J Q Tian Y Zheng T L and Yang X R A nove marine bacterium a gicida to the toxic dinof age ate Alexandrium tamarense Lett Appl Microbiol 512010552557

Wang L Liu L Zheng B Zhu Y and Wang X Anaysis of the bacteria community in the two typica intertida sediments of Bohai Bay China by pyrosequencing Mar Pol ut Bull 722013181187

Wang H Tomasch J T Jarek M and Wagner Döb er A dua-speeies co-species co cu tivation system to study the interactions between Roseobacters and dinof age ates Front Microbiol 52014 e00311

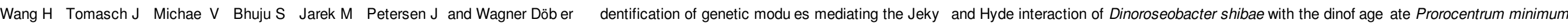
Front Microbiol 6201518

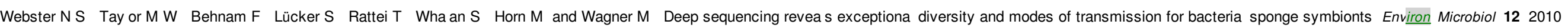
20702082

White J R Nagarajan N and Pop M Statistica methods for detecting differentia y abundant features in c inica metagenomic sampes PLoS Comput Biol 52009 e1000352

Yang C Zhou Y Zheng W Tian Y and Zheng T Bacteria community dynamics during a boom caused by Akashiwo sanguinea in the Xiamen sea area China Harmful Algae 202012132141

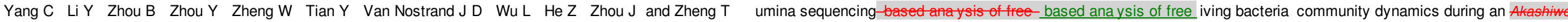
sanguineAkashiwo sanguine boom in Xiamen Sea China Sci Rep 520158476

Yoon J H Kang S J Park S Oh K H and Oh T K Jannaschia seohaensis sp nov iso ated from a tida fat sediment Int J Syst Evol Microbiol 602010191195

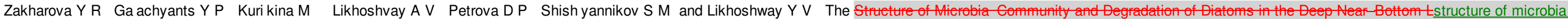
community and degradation of diatoms in the deep near bottom ayer of Lake Baika PLøOOSONE 82013112

Multimedia Component 1

Table S1 Closes ma ches from he NCB GenBank da abase based on sequence similari of he seven OTUs explaining 20\% of he dissimilari y be ween assemblages and bloom phases as revealed by S MPER analysis

Multimedia Component 2

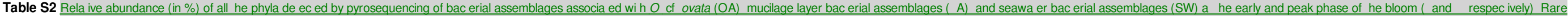
phyla accoun ed for less han $1 \%$ in percen age

Multimedia Component 3

Table S3 Rela ive abundance (in \%) of all he classes de ec ed by pyrosequencing analysis Rare classes accoun ed for less han $1 \%$ in percen age

Multimedia Component 4 


\section{Table 54 Rela ive abundance (in \%) of all he genera de ec ed by pyrosequencing analysis Rare genera accoun ed for less han $1 \%$ in percen age}

\section{Queries and Answers}

Query: The au hor names have been agged as g ven names and surnames (surnames are h gh gh ed $\mathrm{n}$ ea co or) $\mathrm{P}$ ease conf $\mathrm{rm} f$ hey have been den fed correc $\mathrm{y}$ Answer: Yes

Query: The number of keywords prov ded exceeds he max mum of 6 a owed by $h \mathrm{~s}$ journa Pease prov de he fna $s$ of 6 keywords for he ar ce

Answer: Ostreopsis; Tox c d nof age a e; HAB assoc a ed bac er a; Ruegeria; Haliea; Jannaschia

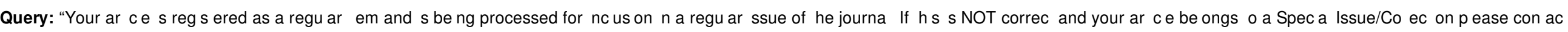
rsknner@esever com mmed a e y pror ore urn ng your correc ons"

Answer: Yes, h s ar ce s reg s ered as a regu ar em and has o be processed for $\mathrm{nc}$ us on $\mathrm{n}$ a regu ar ssue of he journa

Query: Pease check he pacemen of Tab e 3, and correc f necessary

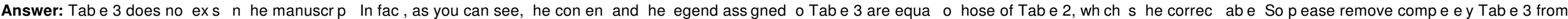
he ar ce

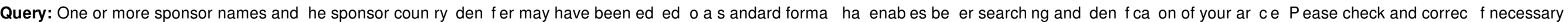
Answer: Yes

Query: P ease upda e Ref "Vanucc e a (n press)"

Answer: No up ade $\mathrm{s}$ ava abe, s $\mathrm{s}$ n press 